\title{
CONCEPTIONS OF AN URBAN AGGLOMERATION AND A METROPOLITAN AREA IN POLAND
}

\author{
TERESA CZYŻ \\ Institute of Socio-Economic Geography and Spatial Management \\ Adam Mickiewicz University \\ Dzięgielowa 27, 61-680 Poznań, Poland \\ E-mail: tczyz@amu.edu.pl
}

\begin{abstract}
The aim of the article is to present the conception of an urban agglomeration and that of a metropolitan area in geography and physical planning as approached by Polish authors. Special attention is paid to relations holding between those conceptions, which are considered in terms of the morphological and the functional structure of a large city. A survey is made of what has been achieved in the delimitation of urban agglomerations and metropolitan areas in Poland. The opinion is expressed that a metropolis and a metropolitan area, which are concentrations of high-order socio-economic functions and internationally ranging links, are settlement forms more highly organised functionally than an urban agglomeration.
\end{abstract}

Key words: urban agglomeration, metropolitan area, high-order functions, networks of international links, Poland

\section{INTRODUCTION}

In the recent years, in geography and spatial management there has been an upsurge of interest in the present-day transformation taking place in Poland's urban system. A manifestation of its evolution is the growth of major cities, development of their functions, and change in their zones of influence. However, in studies addressing this issue one can observe a terminological confusion and lack of agreement on the content of basic notions. This is a consequence of the various terminologies employed by the authors of individual conceptions of urban growth, a semantic modification of some notions, or imprecise use of some terms by researchers.
The aim of this article is to make a survey of basic conceptions concerning spatial and functional structures of major cities in the light of studies by Polish geographers and urban planners, and to sort out notions employed in this field of enquiry. The conceptions dealt with will be primarily those of an urban agglomeration and a metropolitan area, with special attention paid to relations holding between them.

\section{URBAN AGGLOMERATION}

The term 'urban agglomeration', adopted from French geography, appeared in Poland in the 1960 s with reference to the settlement 
system of a large city. The first definition of this notion can be found in Dziewoński and Kosiński (1964), who construed it as an area of a spatial concentration of the population. The first to present an extended definition of an agglomeration as a settlement system of a large city was Iwanicka-Lyra (1969: 22). According to her, an urban agglomeration should be understood to mean "a compact area embracing a core, towns, settlements and those of the surrounding units of administrative division which display higher-than-average values of what are regarded in the given socio-economic conditions as urbanisation measures; urbanisation processes more advanced than elsewhere are the result of close links of the core with its surrounding areas". In Iwanicka-Lyra's conception, a large urban agglomeration displays the following general properties:

- it is an urbanised area embracing towns and urbanised rural areas,

- it consists of a core (a central city) and a surrounding area connected with it, and

- it is a spatially compact area.

In the 1970 s and " 80 s the conception of an urban agglomeration clearly reflected the intensive urbanisation stage Poland was going through at that time. It was a period of a dynamic population increase, expansion of urbanised areas, and extensive industrialisation. In most big cities there occurred the process of relative centralisation, i.e. the population tended to grow in both the core city and its suburban zone, although the growth rate was higher in the city. Differences between the chief urban centre of an agglomeration and its surrounding urbanised areas involved those in the concentration of the population and the economy, largely industrial at the core. The system was dominated, in population and functional terms, by the core city.

In that period many new definitions of an urban agglomeration were proposed in urban geography (Table 1). The morphological aspect of urbanisation decidedly predominated in them over the functional one, and they stressed the role of an urban agglomeration as a node of a socio-economic region.
In defining an urban agglomeration, an attempt was also made at its systems interpretation. According to Dziewoński (1972: 176; 1990: 142), a large urban agglomeration is an urban complex which is a settlement subsystem. In many definitions, the systemic aspects of an agglomeration were presented using various, usually far-fromprecise terms, like set, cluster, complex, pattern, unit, association, functions, integrated whole, closed area, zone of influence, or region. Thus, the systems conception can be a category leading to a unification of all the approaches attempted so far in defining urban agglomerations (Chojnicki 1980). The main systemic aspects that can be employed to define the notion of an urban agglomeration include: composition (element), relations, structure, surroundings, and the property of wholeness. However, tackling an urban agglomeration in a systems approach as a territorial settlement system has not been undertaken and has not provided a basis for a new interpretation of an agglomeration and models of its internal complexity. In the opinion of Jagielski (1989), the systems approach to an urban agglomeration has failed to be tried for its cognitive possibilities, especially in identifying system-forming links in an agglomeration system. However, this type of approach can be found in perceiving an agglomeration as a subsystem in higher-order settlement systems (regional, national).

Studies of the conception of an urban agglomeration were accompanied by empirical work, in particular on the delimitation of such agglomerations. There was an agreement as to the following assumptions:

- the definition of an agglomeration (a node, or a core city with its surrounding urbanised area);

- existence of several hinterland zones differing in the advancement of urbanisation processes;

- integration of the agglomeration through functional links between the hinterland units and the node; and

- continuity and spatial compactness of the agglomeration. 
Table 1. Definitions of an urban agglomeration

\begin{tabular}{ll}
\hline Authors & Definition \\
\hline Leszczycki, Eberhardt, & $\begin{array}{l}\text { An urban agglomeration is a functionally and spatially integrated complex of settlement } \\
\text { units composed of a major city (or cities) as an agglomeration centre and the adjacent } \\
\text { Serman (1971) }\end{array}$ \\
$\begin{array}{l}\text { smaller towns and settlements, as well as villages in which building forms and the } \\
\text { population's occupational structure have transformed in a way qualifying them as } \\
\text { urbanised areas. An agglomeration also includes agricultural, woodland and recreational } \\
\text { areas serving its residents. }\end{array}$
\end{tabular}

Eberhardt, Herman (1973: 30)

Dziewoński (1973: 99)

Korcelli (1976: 591)

Dziewoński et al. (1977)

Rykiel (1978: 12-13)

Jagielski (1989: 81)

Korcelli et al. (1992: 29)
"Within an urban agglomeration one can distinguish complexes of settlement units as spatially continuous systems, while the agglomeration area as a whole is a spatially continuous system."

"A large urban agglomeration is a settlement complex composed of towns and settlements with distinct prevalence of a non-farming population, multi-functional because of its size, and specialising in some lines of production and services at the scale of a country (nation). Being a large concentration of the population, and hence a consumer market, it is therefore able to develop strong and all-encompassing production and service facilities to satisfy its own needs, thus also becoming a central place for the surrounding region and its population, and a strong magnet for a migrating population".

The notion of an urban agglomeration is identical with that of a functional urban region (or a day-time urban system), which "refers to the spheres of direct contact among its inhabitants (so-called spheres of activity) and spatial relations among places of residence, work, education, services, social contacts, and recreation".

An urban agglomeration is a modern form of a big-city settlement system integrated into a single whole through everyday population movement (primarily towards the centre presenting the largest cluster of workplaces and service facilities).

"An urban agglomeration, which is a product of a territorial expansion of the functions of a city, is an economic region whose economy displays a significant and relatively constant level of closure. It is therefore a settlement system satisfying basic needs concerning work, services and housing. (...) An urban agglomeration is a kind of a social whole that has the nature of a large community".

"An agglomeration is a complex, big-city type of settlement unit that can be found at various stages of urbanisation".

"An agglomeration is composed of sets of settlement units with a predominantly nonfarming function and strong functional and spatial links with a nodal area. Due to those links, agglomerations must be seen as systems displaying a high degree of integration".

Source: own compilation.

The criteria of delimitation were largely attributive (inherent) features rather than relational ones (Dziewoński et al. 1977: 324; Rykiel 1978: 13; 2002: 13-15). In substantive terms, the criteria did not differ significantly. Usually employed were demographic indices of urbanisation (population density, proportion of the non-farming population), rarely urban investment and urban land-use indices, or indices of functional links (only journeys to work). The size of the agglomeration centre as measured by the population number was adopted arbitrarily. From 9 to
18 urban agglomerations were distinguished in Poland. Two kinds of boundaries were considered when determining the extent of an agglomeration: ex ante, to be verified in the research procedure, and ex post, resulting from the research.

Studies concerning the delimitation of urban agglomerations served not only cognitive, but also planning goals. In the 1970s, the agglomerations distinguished by Leszczycki, Eberhardt and Heřman (1971), called urban-industrial to emphasise the prominent role of industry in the economic 
base of major cities of those times, were indicated in the Plan of the Country's Spatial Development until 1990 (1974) as the chief links in the nodal-belt pattern of Poland's spatial structure. From the planning perspective, it was also necessary to distinguish not only fully-formed agglomerations (well-developed, corresponding to large urban agglomerations), but also those currently forming (developing) and potential (emerging) ones (Dziewoński and Malisz 1978: 75).

It should be emphasised that planning studies of urban agglomerations were largely conducted at that time in the Institute of Environmental Planning (Jędraszko 1974).

It is worthwhile at this point to state that the delimitation of metropolitan areas carried out in the 1970s on the initiative of the Central Statistical Office rested on a definition identical with that of an urban agglomeration. It is one of the first examples of those terms being used interchangeably (Gontarski 1980)'. Earlier the notion that the Office used for statistical purposes was that of 'urban complexes' as spatially noncontinuous clusters of towns within administrative limits.

In the 1990s the conception of an urban agglomeration is less and less a notional instrument for presenting and understanding the changes taking place in the settlement system of Poland. Urban agglomerations develop dynamically in that period of the socio-economic transformation. The intensifying processes of suburbanisation and deurbanisation bring about structural changes in them. There is advancing decentralisation, which means that the outer agglomeration zone starts to predominate over the central city in terms of the population growth rate. Population deconcentration is accompanied by a deconcentration of socio-economic functions. Relations between centripetal and centrifugal forces change, there develop symmetric links resulting from the comple-

1 Gontarski (1980: 87): a metropolitan area is "a spatially continuous big-city settlement system, composed of administratively separate units, embracing at least one large city or a compact urban area and an urbanised zone connected with it functionally". mentarity of functions in the agglomeration core-suburban zone system and within the suburban zone itself. In the conditions of the systemic transformation, a restructuring of the economic base of agglomerations takes place. At this stage urban agglomerations display a growing complexity of internal and external links, closer integration, and a greater spatial extent. In this situation, to identify the functionally ever more complex settlement systems of major cities, the notion of a metropolitan area gains in significance.

The numerous empirical studies carried out at that time concentrated on analysing urban agglomerations in Poland in terms of population change, economic and spatial transformation, changes in functions, and the dynamics of agglomeration growth in the process of the country's systemic transformation (cf. Korcelli 1996, 1997; Domański 2000; Kołodziejski and Parteka 2001).

The Conception of the Country's Spatial Development Policy (2001) used the term 'europoles' (divided into existing and potential) as a synonym of urban agglomerations. They were seen as "growth engines" of the country's socio-economic development and its integration with the world economy.

\section{METROPOLITAN AREAS AND METROPOLISES}

A metropolitan area is understood as a territorial settlement system with very distinct systemic aspects. Those include: (1) socioeconomic links existing not only around the core city, but within the entire inner system of the metropolitan area; (2) a developed subsystem of daily links between places of residence, work, leisure and public life; (3) the range of certain exogenous links of the centre closed within the settlement network of the area; and (4) the development of external links.

An elucidation of the distinct characters of an urban agglomeration and a metropolitan area was attempted earlier by Korcelli (1973, 1974). According to him (1973: 157-159), "unlike the notion of 'metropoli- 
tan area', that of 'urban agglomeration' conveys primarily a morphological message and refers to an advanced development stage of a settlement system". It is a notion corresponding to that of an urbanised area. "The conception of a metropolitan area is a conception of a spatial functional unit. [...] It is close to the conception of a city-region". Korcelli observes that "the terms 'agglomeration' and 'conurbation' usually appear in approaches emphasising the morphological aspect of a structure, while 'metropolitan area' and 'city-region' can be found in conceptions representing a functional approach" (Korcelli 1974: 88). A metropolitan area is made up of a core city, called a metropolitan centre or metropolis, and a set of settlement units closely integrated with it functionally and spatially. It is a system of connections based on the flow of people, goods, capital, and information, and an area of diffusion of social and economic phenomena.

According to Markowski and Marszał (2006: 16), an urban agglomeration is primarily a morphological unit composed of a set of interrelated settlement units that has developed as a result of the process of concentration around a main urban place or many settlement nuclei. In this the notion of a metropolitan area differs fundamentally: it is a functional unit embracing a large, functionally congruous urban complex whose essence is the appearance of metropolitan functions of an international rank. A metropolitan area shows a tendency to combine two aspects: morphological and functional.

Jędraszko (2005: 263) is of the opinion that differences between an urban agglomeration and a metropolitan area reflect various stages of the urbanisation process: "An urban agglomeration is an earlier stage of development of a functional metropolitan area".

The mesoregional scale of a metropolitan area implies that it is part of a regional settlement system. A metropolitan area can be treated as an equivalent of a functional urban region, a city-region, or a local settlement system (Korcelli 1976, 1981).
The socio-economic functions a metropolitan area fulfils in a region, a country and internationally, called metropolitan functions, are performed by the entire metropolitan area, not only the metropolitan core. However, in presenting the conception of a metropolitan area, Korcelli (1998) concentrates largely on the functional structure of a metropolis (in the sense of a metropolitan core) and the range of its influence (cf. Parysek 2003). According to him, a city put into the category of metropolitan centres (metropolises) must meet the size criterion, and its economy should be dominated by modern high-order service functions of at least regional impact. Korcelli (1998: 88) introduces a hierarchy of metropolitan centres and their corresponding ranges of spatial influence: "The first level is formed by regional metropolises, the second-national metropolises, and the third-international metropolises. National metropolises, apart from their nationally ranging functions, also perform some of regional importance, hence they are cores of their 'own' metropolitan regions. Similarly, international metropolises usually also play functions of national and regional extent". This classification of metropolises is also employed by Markowski and Marszal (2006).

Recently, however, the opinion has appeared that only those cities should be classed as metropolises which perform supra-national functions (Jałowiecki 1999; Korcelli-Olejniczak 2004; Parysek 2005). Korcelli-Olejniczak takes an explicit standpoint on this matter. She assumes that "a metropolis develops (or should develop) functions of a largely supra-national range, or that the performance of those functions differentiates it from non-metropolises, i.e. towns of local, regional or at most national significance" (Korcelli-Olejniczak 2004: 36). As Korcelli (2007: 90) comments, this interpretation of the notion of a metropolis in the context of the modern settlement system means that "a metropolitan centre, to deserve the name, should carry out significant functions of an international range, apart from a broad spectrum of general national functions, and also 
have well-developed spatial systems corresponding to the so-called metropolitan form. Today those criteria are only met by Warsaw". According to Jałowiecki (2007: 87), "a metropolis is not only a big city, although some population potential is indispensable (in the European conditions it is estimated at half a million inhabitants), but also a city operating in a network of international links and having a suitable level of services to handle those relations". Classifications of internationally ranging metropolitan functions have been presented by Jalowiecki (1999), Maik (2003) and Parysek (2003).

In works on the present-day relations between a metropolis (understood as a metropolitan centre) and its surrounding region, the prevailing opinion is that those relations tend to weaken in favour of links between metropolitan centres, both at the national and global levels (Jalowiecki 1999). A different approach to the issue of the metropolismetropolitan region relations is represented by the conception of a net-like distribution of metropolitan functions worked out by Korcelli-Olejniczak (2010). It assumes the metropolitan region taking over some of the metropolitan functions and the appearance of a relative functional balance between the metropolis as the chief centre of the region and subregional towns.

Among the many empirical studies employing the notion of a metropolitan area as a conception organising the research procedure one should mention the following:

(a) Gawryszewski et al. (1998), who seek to establish the metropolitan functions of Warsaw against the background of its metropolitan area (identified with the then Warsaw voivodeship) on the basis of an analysis of the location of metropolitan activities (higher-order services), but without determining the spatial extent of their impact at the regional and supra-regional scales.

(b) Gorzelak and Smętkowski (2005), who first deal with a delimitation of the metropolitan areas of Warsaw, Poznań and the Tri-City on the basis of economic activity indices providing an indirect insight into their inner functional links, and then go on to analyse relations between those metropolitan areas and their own regions (defined as metropolitan regions) on the basis of actual socioeconomic links established in a survey research.

(c) Marszał (2005) and Liszewski (2005), with a procedure delimiting the metropolitan area of Łódź resting on indices of the counter-urbanisation process.

In planning practice, the term employed is that of a metropolitan area rather than an urban agglomeration. The first legal document to use this term was the Physical Planning and Spatial Development Act of 27 March 2003. It did not lay down the criteria on the basis of which the spatial range of metropolitan areas should be determined, and did not establish "whether the delimitation should refer to the present state of development (which is the subject of geographical inquiry), or whether it anticipates the future (planned) state, which is by definition the subject of physical planning" (Jędraszko 2005: 264). The 2003 Act made it a duty to establish metropolitan areas. According to its authors, a metropolitan area is "the area of a core city and the surroundings directly connected with it functionally, established in the Conception of the Country's Spatial Development" (Article 2, Point 9). The Conception "defines the basic elements of the national settlement network, distinguishing metropolitan areas" (Article 47, Clause 2, Point 1). A plan of the spatial development of a voivodeship accommodates metropolitan areas (Article 39, Clause 3, Point 4). "For a metropolitan area, a spatial development plan of the metropolitan area is drawn up as part of the spatial development plan of a voivodeship" (Article 39, Clause 6).

The first planning document based on the Act was the Updated Conception of the Country's Spatial Development (2005) $)^{2}$. It

\footnotetext{
${ }^{2}$ The Updated Conception of the Country's Spatial Development was approved by the Council of Ministers (6 September 2005) and passed on to the Parliament. It was then withdrawn from the Parliament at the instance of the Minister of Regional Development (9 October 2006).
} 
rested on the assumption that in the light of the Act, its role "is limited to indicating metropolitan areas, while a precise delimitation is carried out by the competent territorial self-governments" (p. 9). The document assumed that a metropolitan area was characterised by a concentration of high-order functions, especially services, innovative potential, competitiveness, inner socio-economic cooperation, a network of links with other national and foreign metropolises, and an attractive location. However, the Updated Conception offered no explicit significant properties of metropolitan areas today, so metropolitan features (in the form of functions and links resulting from them) were not translated into criteria of their delimitation. The following assumptions were introduced, referring largely to the structure of a metropolitan area:

- the centre of a metropolitan area (the core city) is 'a large city' (the Act, Article 2, Point 2); the city numbers more than 300 thous. inhabitants, and the metropolitan area, more than 500 thous.;

- a metropolitan area is composed of a core city and directly neighbouring communes, and its characteristic is spatial compactness; and

- in a metropolitan area, the hinterland of its core is a zone of heightened economic and social activity; it embraces communes with high indices of development and its dynamics.

Nine existing (fully formed) metropolitan areas were distinguished: Warsaw, Cracow, Poznań, Wrocław, Tri-City, Silesian, Łódź, Szczecin, and Bydgoszcz-Toruń, and three potential ones: Rzeszów, Lublin and Białystok.

What still remains crucial is establishing the boundaries of a metropolitan area at the voivodeship level. By virtue of the Act, its delimitation comes under the remit of the competent local government authority, which is supposed to highlight the area's regional specificity. I assume as representative of an attempt of this kind the delimitation of the Poznań Metropolitan Area worked out by the Wielkopolska Physical Planning Office in Poznań (2007). The delimitation rested on the definition of a metropolitan area after Gontarski (1980). Assuming ex ante boundaries in the pattern of 76 communes, the distribution of values of 26 indices/criteria was examined. The set of indices included: traditional urbanisation indices, those of a modern structure of the economy, and those of economic activity. In the absence of indices of real-life socio-economic links, it was assumed that the economic activity indices and those of transport accessibility provided information about inner, functional connections induced by the metropolis (cf. Smętkowski 2005). A survey of the various approaches to the delimitation of metropolitan areas in Poland's voivodeships can be found in the work edited by Markowski (2005) under the title Planning and management in metropolitan areas. What deserves special attention owing to the choice of indices reflecting functional aspects of a metropolitan area is the delimitation procedure worked out by Tarkowski (2005).

It is worth adding that voivodeship-level delimitations of metropolitan areas have so far been merely studies. The Updated Conception of the Country's Spatial Development failed to acquire the status of a formal government document.

The other planning document, the $\mathrm{Na}$ tional Development Plan 2007-2013, stresses that a metropolitan area is a 'development category', a place of concentration of modern development measures. At this point the fully formed metropolitan areas listed in the Conception of the Country's Spatial Development should become units of physical planning and development programming within voivodeships. It is proposed that they should be given the legal status of a metropolitan poviat. Their territories are to be delimited and accommodated in voivodeship plans of spatial development.

It is assumed in the National Development Plan that the criteria employed to delimit metropolitan areas can be those defined by ESPON (the European Spatial Planning Observatory Network), a European Union programme in the field of physical planning, 
which Poland joined in 2004. ESPON has introduced the concept of a Metropolitan European Growth Area (MEGA). A MEGA is determined in the basis of a Functional Urban Area (FUA) ${ }^{3}$.

In the first draft of the ESPON programme (2004), from among 1,534 FUAs 76 metropolitan areas (MEGAs) were distinguished characterised by a considerable population number (at least 0.5 million), specialised functions in economic management, high-technology industry, public administration, education, transport, and tourism (Korcelli-Olejniczak 2007; Korcelli 2007). Included in the MEGAs were eight Polish urbanised areas: Warsaw, classed with third-category European metropolises, as well as Katowice, Cracow, Gdańsk-Gdynia, Wrocław, Poznań, Łódź and Szczecin, placed in the lowest, fourth category. "A strong point of Polish cities turned out to be the functions of academic and public administration centres, and a weak point - control functions in the private sector and advanced technology industry" (Korcelli 2007: 98).

In 2006, on the strength of a government decision, the Polish Minister of Regional Development started work on preparing a Polish Spatial Development Concept 2033. Its draft assumed that "metropolitan areas consist of metropolitan centres together with the surrounding urbanised zones connected with them functionally" (Korcelli et al. 2010: 78). A metropolitan centre was defined on the basis of the following criteria: a core city which had attained a population size of 300,000; significant functions of at least supra-regional reach; and the presence of an urban complex. Ten metropolitan centres were distinguished: Warsaw (the state-capital metropolis), Cracow, Gdańsk (GdańskGdynia), Wroclaw, Poznań, Katowice (the Upper Silesian conurbation), Łódź, Szczecin, Bydgoszcz (Bydgoszcz-Toruń), and Lublin. The last three are prospective in nature. A metropolitan area includes, apart

${ }^{3}$ A Functional Urban Area (FUA) is defined as a travel-to-work area. FUAs embrace towns with a population of at least 50 thousand (Antikainen 2005: 448). from the metropolitan centre (the core city), other towns neighbouring it, as well as the surrounding poviats connected functionally with the main centre or the remaining towns of this system. A metropolitan area meets the condition of spatial continuity (Fig. 1).

Thus, one can state that the presented rules of metropolitan area delimitation in Poland clearly draw from the conception of MEGAs introduced in ESPON. Each metropolitan area is a subset of the set of Functional Urban Areas (FUAs) connected with and formed around a metropolitan centre.

\section{SUMMING UP}

In the light of the notional analysis presented, is the replacement of the term 'urban agglomeration' by the term 'metropolitan area' justified and valid in cognitive and planning practice terms? An answer might look as follows:

(1) A metropolitan area is a settlement form higher organised functionally than an urban agglomeration.

(2) The conception of a metropolitan area was supposed to expand and deepen the approach to the settlement system of a modern city in terms of its internal and external functional links. However, the notion of a metropolitan area itself has been poorly defined so far. Describing it as "a large city and the immediate surroundings connected with it functionally" is practically also the definition of an urban agglomeration. In turn, a systems approach to a metropolitan area resorting to the conception of a territorial settlement system is formulated in too general terms that need substantive interpretation, and hence is of little help.

(3) It is essential to work out an operational definition of a metropolitan area which would list its significant modern properties necessary and sufficient for its identification, and useful in practice.

(4) The characterisation of development properties of extensive functional ur- 


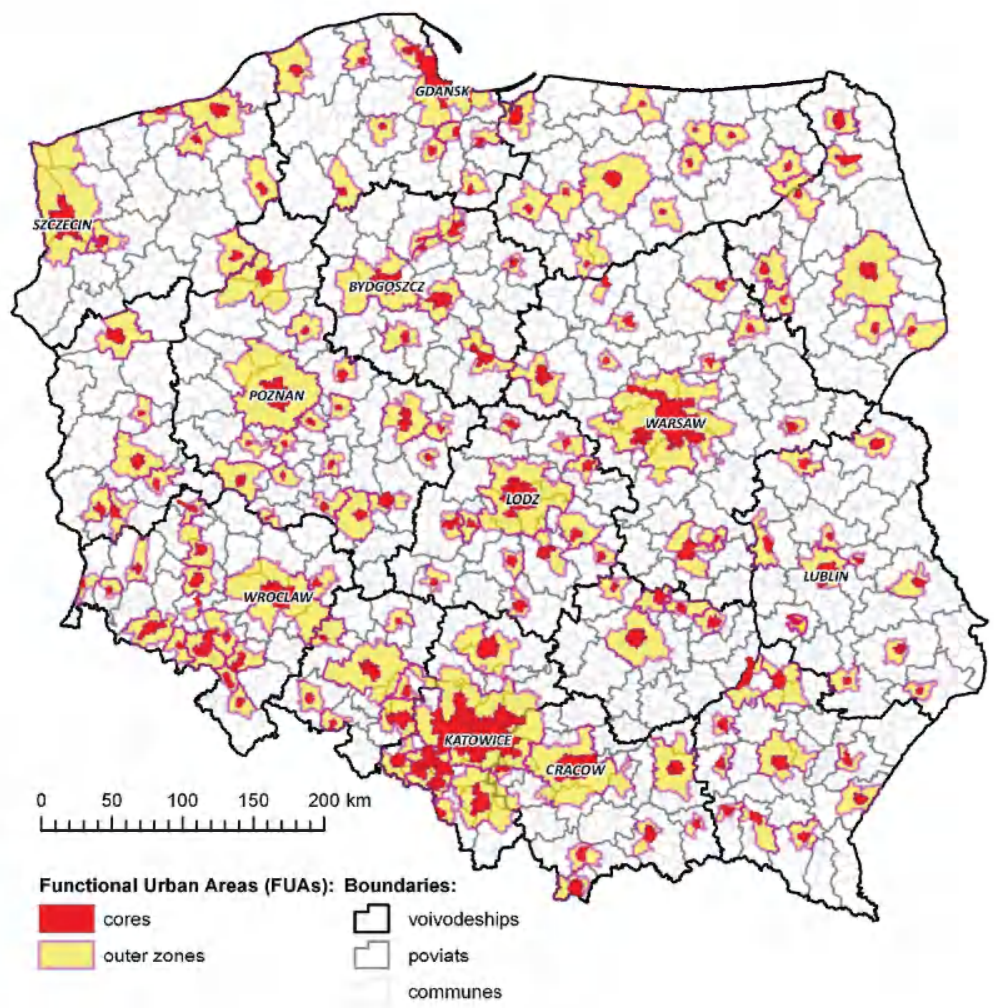

Figure 1. Functional Urban Areas in Poland

Source: after Korcelli et al. 2010:27

ban areas in Poland should rest on the stratification of urban functions according to the relation of precedence into functions of a regional, a national, and a supra-national (international) range. Using this distinction to clarify notions, the term 'urban agglomeration' could be employed to denote a regional or a national centre, and the terms 'metropolitan area' and 'metropolis' only with reference to a major city with well-developed international functions.

It is worth mentioning at this point that a similar terminology is employed by Krätke (2007) in his analysis of the European urban system. He introduces a division of big urban areas (over 1 million inhabitants) into urban agglomerations and metropolitan regions, the latter treated as a category of ur- ban agglomerations standing out for their level of development of functions and economic potential ${ }^{4}$. In Krätke's classification, Warsaw is a metropolitan region, while Katowice, Cracow, Poznań, Wroclaw, Łódź and Gdańsk are urban agglomerations.

\footnotetext{
${ }^{4}$ It should be explained that in modern urban geography 'metropolitan region' and 'metropolitan area' are notions employed side by side (and sometimes interchangeably). The classic conception of a metropolitan region assumes, in turn, that the division of a highly urbanised country into metropolitan regions is exhaustive, i.e. embracing the entire territory of a country (Korcelli 1998: 88-89). Metropolitan regions in this interpretation are first-order regions in the country's regional structure. They differ from metropolitan areas not only in the spatial scale, but also in the character and degree of closure of socio-economic links. According to Rykiel (2002: 13), in Poland the term 'metropolitan region' has been employed in a different sense, namely that of an urban agglomeration or an urban complex (cf. Lier 1965).
} 
(5) In the cognitive studies of metropolises carried out in Poland, one should pass from an examination of the socioeconomic functions of a metropolis to an analysis of the network of its links with other metropolises, and to testing the hypothesis about a weakened link of a metropolis with its surrounding region. Methodological standards for this type of research can be found in Taylor (2001), Taylor and Derudder (2004), and Taylor et al. (2007). This approach to the development of metropolises draws on Berry's (1964) conception of a city as a system, which has since been employed in model solutions (cf. Maik 2008).

\section{REFERENCES}

Aglomeracje miejskie w Polsce. Pojęcie i terminologia [Urban agglomerations in Poland. Concept and terminology] (1973), Warszawa, Biuletyn KPZK PAN, 79.

Antikainen, J. (2005), The concept of Functional Urban Area. Findings of the ESPON Project 1.1.1., Informationen zur Raumentwicklung, 7.

Berry, B.J.L. (1964), Cities as systems within systems of cities, Papers and Proceedings of the Regional Science Association, 13: 147-163.

Chojnicki, Z. (1980), Podstawy prognozowania regionalnych systemów osadniczych [Foundations of forecasting regional settlement systems], Przeglad Geograficzny, 53(4): 495-704.

Czyż, T. (2009), Koncepcje aglomeracji miejskiej i obszaru metropolitalnego w Polsce [Conception of the urban agglomeration and metropolitan area in Poland, Przeglad Geograficzny, 84, 4: 445-461.

Domański, R. (ed.) (2000), Nowe problemy rozwoju wielkich miast i regionów [New problems of development of big cities and regions], Warszawa, Biuletyn KPZK PAN, 192.

Dziewoński, K. (1972), Przeglad teorii sieci osadniczej [A survey of settlement network theories], in Secomski K. (ed.), Elementy teorii planowania przestrzennego, Warszawa, PWN, 163-181.

Dziewoński, K. (1973), W sprawie podstawowych pojęć i terminów używanych w analizie i pla- nowaniu wielkich aglomeracji miejskich [On basic notions and terms employed in the analysis and planning of large urban agglomerations], Biuletyn KPZK PAN, 79: 91-100.

Dziewoński, K. (1990), Koncepcje i metody badawcze $\mathrm{z}$ dziedziny osadnictwa [Conceptions and research methods in the field of settlement], Wroclaw, Prace Geograficzne 45, Instytut Geografii i Przestrzennego Zagospodarowania (IGiPZ), PAN.

Dziewoński, K., Gawryszewski, A., IwanickaLyra, E., Jelonek, A., Jerczyński, M. and Węclawowicz, G. (1977), Rozmieszczenie i migracje ludności a system osadniczy Polski Ludowej [Population distribution and migrations and the settlement system of People's Poland], Wroclaw, Prace Geograficzne 117, Instytut Geografii i Przestrzennego Zagospodarowania (IGiPZ), PAN .

Dziewoński, K. and Kosiński, L. (1964), Rozmieszczenie ludności w Polsce w XX w. [Population distribution in Poland in the 20th century], Przeglad Geograficzny, 36 (1): 3-36.

Dziewoński, K. and Malisz, B. (1978), Przekształcenia przestrzenno-gospodarczej struktury kraju [Transformations of Poland's spatialeconomic structure], Warszawa, Studia KPZK $P A N, 62$.

Eberhardt, P., Her̆man, S. (1973), Podstawowe pojęcia dotyczące zagadnień aglomeracji miejskich [Basic notions concerning urban agglomeration issues], Warszawa, Biuletyn KPZK PAN, 79, 29-41.

ESPON project 1.1.1 (2004), The role, specific situation and potentials of urban areas as nodes of polycentric development. Final Report. The ESPON Programme: <www.espon.eu>.

Gawryszewski, A., Korcelli, P. and Nowosielska, E. (eds.) (1998), Funkcje metropolitalne Warszawy [Warsaw's metropolitan functions], Warszawa, Zeszyty IGiPZ PAN, 53.

Gontarski, Z. (1980), Obszary metropolitalne w Polsce [Metropolitan areas in Poland], Warszawa, Biuletyn KPZK PAN, 109.

Gorzelak, G. and Smętkowski, M. (2005), Metropolia i jej region $w$ gospodarce informacyjnej [Metropolis and its region in an information economy], Centrum Europejskich Studiów Regionalnych i Lokalnych UW, Warszawa, Wydawnictwo Naukowe Scholar. 
Iwanicka-Lyra, E. (1969), Delimitacja aglomeracji wielkomiejskich w Polsce [Delimitation of urban agglomerations in Poland], Warszawa, Prace Geograficzne 76, Instytut Geografii i Przestrzennego Zagospodarowania (IGiPZ), PAN.

Jagielski, A. (1989), Aglomeracje miejskie i migracje stale w systemie osadniczym [Urban agglomerations and permanent migrations in a settlement system], in Korcelli, P. and Gawryszewski, A. (eds), Współczesne przemiany regionalnych systemów osadniczych w Polsce, Prace Geograficzne 152, Instytut Geografii i Przestrzennego Zagospodarowania (IGiPZ), PAN, 78-88.

Jałowiecki, B. (1999), Metropolie [Metropolises], Białystok, Wyższa Szkoła Finansów i Zarządzania w Białymstoku.

Jałowiecki, B. (2005), Polskie miasta w procesie metropolizacji [Polish cities in the process of metropolitanisation], Studia Regionalne $i$ Lokalne, Warszawa, Uniwersytet Warszawski, 1 (19): 5-15.

Jałowiecki, B. (2007), Globalny świat metropolii [The global world of metropolises], Warszawa, Wydawnictwo Naukowe Scholar.

Jędraszko, A. (ed.) (1974), Planowanie aglomeracji miejskich $w$ Polsce. Metoda, delimitacja, program badań [Planning urban agglomerations in Poland. Method, delimitation, research programme], Warszawa, Instytut Kształtowania Środowiska.

Jędraszko, A. (ed.) (2005), Zagospodarowanie przestrzenne $w$ Polsce-drogi $i$ bezdroża regulacji ustawowych [Spatial development in Poland: Pathways and blind alleys of legal regulations]. Warszawa, Nakładem Unii Metropolii Polskich.

Kołodziejski, J. and Parteka, T. (2001). Kształtowanie ładu przestrzennego polskich metropolii $\mathrm{w}$ procesie transformacji ustrojowej III RP [Moulding the spatial order of Polish mteropolises in the process of the systemic transformation of the Third Polish Republic], Warszawa, Biuletyn KPZK PAN, 193.

Koncepcja Polityki Przestrzennego Zagospodarowania Kraju [Conception of the Country's Spatial Development Policy] (2001), Monitor Polski Nr 26, 503-595.
Korcelli, P. (1973), Głos w dyskusji [A voice in the discussion], in Aglomeracje miejskie w Polsce. Pojęcie i terminologia, Warszawa, Biuletyn KPZK PAN, 79: 157-159.

Korcelli, P. (1974), Teoria rozwoju struktury przestrzennej miast [Theory of the development of the spatial structure of towns], Warszawa, Studia KPZK PAN, 95.

Korcelli, P. (1976), Aglomeracje miejskie w systemach osadniczych [Urban agglomerations in settlement systems], Przeglad Geograficzny, 48 (4): 589-599.

Korcelli, P. (1981), Regiony miejskie w systemie osadniczym Polski [Urban regions in Poland's settlement system], in Dziewoński K. and Korcelli P. (eds), Studia nad migracjami i przemianami systemu osadniczego w Polsce, Warszawa, Prace Geograficzne 140, Instytut Geografii i Przestrzennego Zagospodarowania (IGiPZ), PAN: 189-212.

Korcelli, P. (ed.) (1996), Aglomeracje miejskie w procesie transformacji: I, II [Urban agglomerations in the transformation process], Warszawa, Zeszyty IGiPZ PAN, 41-42.

Korcelli, P. (ed.) (1997), Aglomeracje miejskie w procesie transformacji: III [Urban agglomerations in the transformation process], Warszawa, Zeszyty IGiPZ PAN, 43.

Korcelli, P. (1998), Metropolia i funkcje metropolitalne-podstawowe pojęcia i ich zakres [Metropolis and metropolitan functions: Basic notions and their range], in Gawryszewski A., Korcelli P. and Nowosielska E. (eds), Funkcje metropolitalne Warszawy, Warszawa, Zeszyty IGiPZ PAN, 53: 84-90.

Korcelli, P. (2007), Podstawowe węzły układu osadniczego Polski na tle europejskiego systemu osadniczego (aglomeracje-metropolie) [Basic nodes of Poland's settlement system as compared with the European settlement system (agglomerations-metropolises)], Warszawa, Biuletyn KPZK PAN, 233: 87-113.

Korcelli, P., Gawryszewski A. and Potrykowska A. (1992), Przestrzenna struktura ludności Polski. Tendencje i perspektywy [Spatial structure of Poland's population. Tendencies and prospects], Warszawa, Studia KPZK PAN, 98.

Korcelli, P., Degórski M., Drzazga D., Komornicki T., Markowski T., Szlachta J., Węcławowicz G., Zalewski J. and Zaucha J. (2010). 
Ekspercki Projekt Koncepcji Przestrzennego Zagospodarowania Kraju do roku 2033 [Polish Spatial Development Concept 2033: An Expert's Approach], Warszawa, Studia KPZK $P A N, 128$.

Korcelli-Olejniczak, E. (2004), Funkcje metropolitalne Berlina i Warszawy w latach 1990-2002. Współzależność pozycji w systemie miast Europy Środkowej [Metropolitan functions of Berlin and Warsaw in the years 1990-2002. Co-dependence of positions in the European urban system], Warszawa, Prace Geograficzne 198, Instytut Geografii i Przestrzennego Zagospodarowania (IGiPZ), PAN.

Korcelli-Olejniczak, E. (2007), Metropolitan functions as a research question: definitions and identifications in the ESPON and alternative approaches, GaWC, Research Bulletin 248(A): <http://www.lboro.ac.uk/gawc/rb/ rb248.html>

Korcelli-Olejniczak, E. (2010), Kształtowanie się regionu metropolitalnego Warszawy w świetle analizy zasięgu działalności przedsiębiorstw sektora zaawansowanych usług [Warsaw metropolitan region in the making: An analysis of the range of activity of firms of the advance service sector]. Przeglad Geograficzny, 82 (4): 573-592.

Krätke, S. (2007), The metropolization of the European urban system in the era of globalization, in Taylor, P.J., Derudder, B., Saey, P. and Witlox, F. (eds), Cities in globalization. Practices, policies and theories, London, Routledge, 157-183.

Leszczycki, S., Eberhardt, P., Her̆man, S. (1971), Aglomeracje miejsko-przemyslowe w Polsce 1966-2000 [Urban-industrial agglomerations in Poland, 1966-2000], Warszawa, Biuletyn KPZK PAN, 67.

Lier, K. (1965), Region metropolitalny Warszawy. Próba delimitacji [Warsaw metropolitan region: An attempt at delimitation], Warszawa, Biuletyn KPZK PAN, 35: 50-86.

Liszewski, S. (2005), Delimitacja obszaru metropolitalnego Łodzi [Delimitation of the Łódź metropolitan area], Warszawa, Biuletyn KPZK PAN, 215: 25-47.

Maik, W. (1992), Podstawy geografii miast [Basics of urban geography], Toruń, Uniwersytet Mikołaja Kopernika.
Maik, W. (2003), Pojęcie metropolii a problem badania funkcji metropolitalnych [Concepts of a metropolis and the problem of studying metropolitan functions], in Jażdżewska I. (ed.), Funkcje metropolitalne $i$ ich rola $w$ organizacji przestrzeni, XVI Konwersatorium Wiedzy o Mieście, Łódź, Uniwersytet Łódzki, 9-17.

Maik, W. (2008), Ewolucje teoretyczno-metodologiczne studiów miejskich $w$ świetle zmieniajacych się konceptualizacji miasta [Theoreticalmethodological evolution of urban studies in the light of changing conceptualisations of the city], in Parysek, J.J. and Stryjakiewicz, T. (eds), Region spoleczno-ekonomiczny i rozwój regionalny, Poznań, Bogucki Wydawnictwo Naukowe, 77-90.

Markowski, T. (ed.) (2005), Planowanie i zarządzanie w obszarach metropolitalnych [Planning and management in metropolitan areas], Warszawa, Biuletyn KPZK PAN, 221.

Markowski, T., Marszal T. (2006), Metropolie, obszary metropolitalne, metropolizacja. Problemy i pojecia podstawowe [Metropolises, metropolitan areas, metropolitanisation: Basic problems and notions], Warszawa, KPZK PAN.

Marszal, T. (2005), Funkcje obszaru metropolitalnego Łodzi [Functions of the Łódź metropolitan area], Warszawa, Biuletyn KPZK $P A N, 215: 49-109$.

Parysek, J.J. (2003), Metropolie: metropolitalne funkcje i struktury przestrzenne [Metropolises: metropolitan functions and spatial structures], in Jażdżewska, I. (ed.), Funkcje metropolitalne i ich rola $w$ organizacji przestrzeni, XVI Konwersatorium Wiedzy o Mieście, Łódź, Uniwersytet Łódzki, 19-40.

Parysek, J.J. (2005), Miasta polskie na przetomie XX. i XXI wieku. Rozwój i przeksztatcenia strukturalne [Polish towns in the late 20th and early 21st centuries], Poznań, Bogucki Wydawnictwo Naukowe.

Plan Przestrzennego Zagospodarowania Kraju do roku 1990 (1974) [Plan of the Country's Spatial Development until 1990], Warszawa, Biuletyn KPZK PAN, 85.

Poznański Obszar Metropolitalny [Poznań Metropolitan Area] (2006), Poznań, Wielkopolskie Biuro Planowania Przestrzennego w Poznaniu. 
Rykiel, Z. (1978), Miejsce aglomeracji wielkomiejskich w przestrzeni społeczno-gospodarczej Polski [Place of urban agglomerations in Poland's socio-economic space], Wrocław, Prace Geograficzne 128, Instytut Geografii i Przestrzennego Zagospodarowania (IGiPZ), PAN.

Rykiel, Z. (2002), Koncepcje i delimitacje wielkomiejskich form osadniczych $w$ Polsce [Conceptions and delimitations of big-city settlement forms in Poland], in Jażdżewska, I. (ed.), Wspótczesne formy osadnictwa miejskiego i ich przemiany, XV Konwersatorium Wiedzy o Mieście, Łódź, Uniwersytet Łódzki, 9-19.

Smętkowski, M. (2005), Rola infrastruktury transportowej $\mathrm{w}$ integracji obszaru metropolitalnego Warszawy [Role of transport infrastructure in the integration of the Warsaw metropolitan area], Warszawa, Biuletyn KPZK PAN, 222: 45-63.

Tarkowski, M. (2005), Dzienny system miejski jako metropolitalny obszar statystyczny-propozycja delimitacji [Day-time urban system as a statistical metropolitan area: 'A delimitation proposal], in Markowski, T. (ed.), Planowanie i zarządzanie w obszarach metropolitalnych, Warszawa, Biuletyn KPZK PAN, 221: 95-104.
Taylor, P.J. (2001), Specification of the world city network, Geographical Analysis, 33 (2): 181-194.

Taylor, P.J., Derudder, B. (2004), Porous Europe: European cities in global urban areas, Tijdschrift voor Economische en Sociale Geografie, 95 (5): 527-538.

Taylor, P.J., Derudder, B., Saey, P. and Witlox, F. (2007), Cities in globalization. Practices, policies and theories, London, Routledge.

Zaktualizowana Koncepcja Przestrzennego Zagospodarowania Kraju [Updated Conception of the Country's Spatial Development] (2005), Warszawa, Rządowe Centrum Studiów Strategicznych.

Paper first received: July 2011

In final form: September 2011 
